\title{
Suppression of Cell-mediated and Humoral Immune Responses by an Interleukin-2-Immunoglobulin Fusion Protein in Mice
}

\author{
Ulrich Kunzendorf, ${ }^{\star}$ Thomas Pohl, ${ }^{\star}$ Silvia Bulfone-Paus, ${ }^{*}$ Hans Krause, ${ }^{*}$ Michael Notter, ${ }^{*}$ Adrian Onu, ${ }^{\star}$ Gerd Walz, ${ }^{\ddagger}$ \\ and Tibor Diamantstein* \\ *Institute of Immunology, Universitätsklinikum Benjamin Franklin, Berlin, Germany; and ${ }^{\ddagger}$ Renal Division, Beth Israel Hospital, \\ Harvard Medical School, Boston, Massachusetts 02138
}

\begin{abstract}
Interleukin-2 (IL-2) plays a pivotal role in the cellular and humoral immune responses directed against foreign antigens. We characterized the in vitro and in vivo properties of a chimeric protein consisting of mouse IL-2 fused to the mouse IgG2b Fc domains. This fusion protein binds to IL-2 and Fc receptors and supports IL-2-dependent cell proliferation but does not mediate lysis of IL-2 receptor-positive cells in the presence of murine complement in vitro. However, in vivo the IL2-IgG2b fusion protein suppresses both cellular and humoral immune responses after immunization with sheep erythrocytes. Surprisingly, delayed hypersensitivity is inhibited despite a dramatic increase of splenic $\mathrm{CD3}+$ and NK1.1+ lymphocytes, indicating that altered homing of IL2-IgG2b-activated lymphocytes rather than cytolysis prevents these cells from accumulating in areas of inflammation. Although in vitro the IL2-IgG2b fusion protein does not alter proliferation of $\mathrm{B}$ cells in response to mitogenic stimulation, IgM production in response to sheep erythrocytes is profoundly inhibited in mice treated with the IL2-IgG2b fusion protein. Since no side effects are observed, the IL2-IgG2b fusion protein may expand the therapeutic repertoire of reagents used for the treatment of allograft rejection and autoimmune diseases. (J. Clin. Invest. 1996. 97: 1204-1210.) Key words: fusion proteins • immunoligands • immunosuppression • cell-mediated immune response
\end{abstract}

\section{Introduction}

Current concepts for the treatment of autoimmune diseases as well as the prevention of allograft rejection rely on the efficacy of drugs such as cyclophosphamide, azathioprine, and cyclosporine that interfere with the immune response abrogating cytokine production and cell proliferation. Side effects and dose-limiting toxicity result from their limited specificity for the immune system. A more specific approach to inhibit selective immune function became feasible with the application of monoclonal antibodies. Anti-CD3, anti-CD4, and anti-CD25 antibodies are highly effective and block T cell-mediated im-

Address correspondence to Dr. Ulrich Kunzendorf, UniversitätsKlinikum Benjamin Franklin, Abt. für Innere Medizin, Hindenburgdamm 30, D-12200 Berlin, Germany. Phone: 30-8445-2441; FAX: 30-8445-4141.

Received for publication 24 July 1995 and accepted in revised form 7 December 1995.

J. Clin. Invest.

(C) The American Society for Clinical Investigation, Inc.

0021-9738/96/03/1204/07 \$2.00

Volume 97, Number 5, March 1996, 1204-1210 mune responses in vitro and in vivo (1-4). Recently, genetically engineered immunoligands such as CTLA4-IgG or IL2$\operatorname{IgM}$ were used successfully to modulate the immune response to xeno-, allo-, and autoantigens (5-8). How these different reagents exert their immunomodulatory functions remains unclear. While depleting monoclonal antibodies against CD3 or CD4 may eliminate T cells, the modes of action for nondepleting antibodies as well as CTLA4 and IL-2 fusion proteins are less clearly defined.

This study analyzes the in vitro and in vivo properties of a murine IL2-IgG2b chimeric protein ${ }^{1}$ in an attempt to understand its profound effects on $\mathrm{T}$ and $\mathrm{B}$ cell-mediated immune responses.

\section{Methods}

Production of IL2-IgG2b fusion proteins. Mouse IL-2 cDNA was amplified by PCR using reverse-transcribed total RNA of ConA-activated spleen $T$ cell blasts according to published protocols (9). The forward primer used contained a HindIII restriction site upstream of the translational start codon ( $5^{\prime}$ ctcaagaagcttagccatgtacagcatgcagctc), and the reverse primer contained a BamHI restriction site in place of the IL-2 translational stop codon (5' gtacatggatcctgagggcttgttgagatg). The IL-2 PCR products were digested with BamHI and partially digested with HindIII. Since the IL-2 cDNA contains an internal HindIII site at position 378, only the digested full-length IL-2 cDNA was ligated into the HindIII-BamHI-cut CD16-IgG2b-CDM8 vector, which was provided by Seed and Aruffo (10). Subsequently, COS cells were transfected with $4 \mu \mathrm{g}$ of plasmid DNA using the DEAE/ dextran method (11). $7 \mathrm{~d}$ after transfection, the supernatant was harvested, centrifuged to remove cell debris, and stored at $4^{\circ} \mathrm{C}$ until use. To obtain greater amounts of fusion proteins, we used a Baculo-virus expression system (Invitrogen, DeSchelp, Belgium). The IL2-IgG2b fusion gene was prepared from the IL2-IgG2b-CDM8 plasmid by HindIII/NotI digest and cloned into the Baculo-virus transfer vector pBlueBacIII after modification of the polylinker. Recombinant Baculo-virus preparations were obtained by linear transfection, as suggested by the manufacturer (Invitrogen). Plaques were selected by $\beta$-Gal staining and visual inspection for the occ ${ }^{-}$phenotype. Recombinant Baculo-viruses were purified through several rounds of plaque assays. Infected High Five cells (Trichoplusia ni; Invitrogen) adherently growing in roller bottles in protein-free medium (Insect Express; BioWhittaker, Inc., Walkersville, MD) released $\sim 5-10 \mu \mathrm{g} \mathrm{fu}-$ sion $\operatorname{protein} / \mathrm{ml}$ into the supernatant, which was harvested $72-96 \mathrm{~h}$ after infection.

Quantification of chimeric proteins by ELISA. The concentration of the fusion proteins was determined by an ELISA for the murine IgG-Fc domains. 96-well microtiter plates (Nunc, Wiesbaden, Germany) were coated with a rat anti-mouse Fc-specific polyclonal antibody (5 $\mu \mathrm{g} \mathrm{IgG/ml} \mathrm{PBS;} \mathrm{DAKO,} \mathrm{Hamburg,} \mathrm{Germany).} \mathrm{After} \mathrm{the}$

1. Abbreviations used in this paper: DTH, delayed type hypersensitivity; IL2-IgG2b, chimeric protein consisting of mouse IL-2 fused to the Fc part of mouse IgG2b; SRBC, sheep red blood cells. 
plates were blocked by $3 \%$ BSA/PBS, the cell supernatants containing fusion proteins or serial dilutions of mouse $\operatorname{IgG}(0.1-5 \mu \mathrm{g} \mathrm{IgG}$ in $1 \%$ BSA/PBS; DAKO) were added in duplicates, and plates were incubated with rat anti-mouse Fc-specific alkaline phosphatase-conjugated polyclonal antibody ( $1 \mu \mathrm{g}$ IgG/1 ml PBS; DAKO). Thereafter, $50 \mu \mathrm{l}$ of substrate for the alkaline phosphatase was added (1 $\mathrm{mg} p$-nitrophenyl phosphate disodium [Sigma Immunochemicals, St. Louis, $\mathrm{MO}] / \mathrm{ml}$ buffer $[0.9 \mathrm{M}$ diethanolamine, $0.5 \mathrm{mM}$ magnesium dichloride, $\mathrm{pH}$ 9.8]). After $30 \mathrm{~min}$, the absorbance was determined by an automated ELISA reader at $405 \mathrm{~nm}$. The plates were washed four times between each incubation.

Protein purification. Fusion protein containing supernatant was adjusted to $\mathrm{pH} 7.4$ and batch-extracted with 0.5 grams/liter protein A-Sepharose CL4B (Pharmacia Biotech Inc., Piscataway, NJ) for $16 \mathrm{~h}$ at $4^{\circ} \mathrm{C}$. After binding, protein A-Sepharose was collected in disposable plastic columns, washed with $50 \mathrm{mM}$ Tris- $\mathrm{Cl}, \mathrm{pH}$ 7.4, $150 \mathrm{mM}$ $\mathrm{NaCl}$ buffer, and the fusion proteins were eluted with $1 \mathrm{M}$ acetic acid. After dialysis against PBS, fusion proteins were snap-frozen in liquid nitrogen and stored in aliquots at $-80^{\circ} \mathrm{C}$. For SDS-PAGE analysis, $5 \mu \mathrm{g}$ of purified fusion protein was loaded on a $10 \%$ discontinuous polyacrylamide gel with or without prior exposure to dithiothreitol. Proteins were visualized by staining with Coomassie blue.

Functional characterization of IL2-IgG2b in vitro. Detection of IL2IgG2b binding to IL-2 receptor-positive CTLL-16 cell lines was carried out by indirect immunofluorescence. $10^{6}$ CTLL-16 cells were incubated with IL2-IgG2b or CD16-IgG2b as a control fusion protein in a final concentration of $1 \mu \mathrm{g} / \mathrm{ml} \mathrm{COS}$ cell supernatant or Baculovirus supernatant of the same concentration at $4^{\circ} \mathrm{C}$ for $30 \mathrm{~min}$. Recombinant human IL-2 in a final concentration of $500 \mu \mathrm{g} / \mathrm{ml}$ (Cetus Corp., Emeryville, CA) was added to specifically inhibit binding of IL2-IgG2b to the IL-2 receptor. Cells were washed and resuspended in 50- $\mu$ l goat anti-mouse FITC $\mathrm{F}\left(\mathrm{ab}^{\prime}\right) 2$ fragments (Immunotech, Marseille, France). Detection of IL2-IgG2b binding to IL-2 receptornegative cells via the Fc receptor was performed with the mouse macrophage-like cell line WEHI-3 (American Type Culture Collection, Rockville, MD). After incubation, $10^{6}$ WEHI- 3 cells in $1 \mu \mathrm{g} / \mathrm{ml} \mathrm{IL2-}$ $\mathrm{IgG} 2 \mathrm{~b}$ diluted either in staining buffer or in staining buffer containing $25 \%$ mouse serum cells were washed and resuspended in $50 \mu \mathrm{l}$ of rat anti-mouse IL-2 FITC (Pharmingen, Hamburg, Germany). Stained cells were analyzed on a FACScan ${ }^{\circledR}$ (Becton Dickinson, Mountain View, CA). In addition, IL-2 activity was assayed by incubating $5 \times$ $10^{4}$ mouse spleen cells prepared from 6-8-wk-old BALB/c mice (Bomholtgard, Ly, Denmark), T lymphoblasts prepared as described (12), or IL-2-dependent mouse CTLL-16 cells for $18 \mathrm{~h}$ with serial dilutions of IL2-IgG2b (0-96 ng/ml) or mouse IL-2 (0-24 ng/ml) (Genzyme Corp., Cambridge, MA) in a total volume of $200 \mu \mathrm{l}$. After $18 \mathrm{~h}$, $1 \mu \mathrm{Ci}$ of $\left[{ }^{3} \mathrm{H}\right]$ thymidine was added, and cells were incubated for an additional $4 \mathrm{~h}$. Radioactivity was quantified by scintillation counting. Furthermore, we tested the potency of cell-bound IL2-IgG2b to support proliferation of CTLL-16 cells. $5 \times 10^{6} \mathrm{WEHI}-3$ cells were inactivated with $100 \mu \mathrm{g} / \mathrm{ml}$ mitomycin $\mathrm{C}$ at $37^{\circ} \mathrm{C}$ for $30 \mathrm{~min}$, washed, and coated either with $50 \mu \mathrm{g} / \mathrm{ml}$ IL2-IgG2b or $50 \mu \mathrm{g} / \mathrm{ml} \mathrm{CD16-IgG2b}$. Treated WEHI- 3 cells $\left(0.08-5 \times 10^{4}\right.$ cells/well in a serial dilution $)$ were coincubated with $5 \times 10^{3} /$ well CTLL- 16 cells, and proliferation of CTLL16 cells was measured by $\left[{ }^{3} \mathrm{H}\right]$ thymidine incorporation, as described above. To determine the influence of IL2-IgG2b on B cell activation, murine $\mathrm{B}$ cells were prepared from 6-8-wk-old nude $\mathrm{BALB} / \mathrm{c}$ female mice (Bomholtgard). Cell suspensions from minced spleens were centrifuged over Ficoll-Hypaque, washed, and then incubated for $4 \mathrm{~h}$ at $37^{\circ} \mathrm{C}$ in flat-bottomed culture dishes to remove adherent cells. The resulting preparation contained $>95 \%$ B cells. $10^{5}$ cells were incubated in $100 \mu \mathrm{l}$ RPMI medium containing 0 , 1 , or 10 $\mu \mathrm{g} / \mathrm{ml}$ IL2-IgG2b supplemented with LPS in a final concentration of 0,5 , or $50 \mu \mathrm{g} / \mathrm{ml}$ for 24 or $48 \mathrm{~h}$. B cell proliferation was measured by $\left[{ }^{3} \mathrm{H}\right]$ thymidine incorporation as described above. In addition, complement fixation was carried out by precoating $10^{651} \mathrm{Cr}$-labeled CTLL-16 cells with rat anti-mouse CD25 mAb AMT13 (12), IL2-IgG2b, or control fusion protein CD16-IgG2b for $45 \mathrm{~min}$ at $4^{\circ} \mathrm{C} .100 \mu \mathrm{l}$ of a $\log$
2 dilution (1:2 to 1:256) of mouse serum, mouse plasma, or rabbit complement (Behringwerke, Marburg, Germany) was added to $10^{4}$ cells in $100 \mu \mathrm{l}$, and samples were incubated for $45 \mathrm{~min}$ at $37^{\circ} \mathrm{C}$. NP-40 (1\%) was substituted for complement to determine the total radioactive release. After incubation, ${ }^{51} \mathrm{Cr}$ release was determined. Results were expressed as: specific lysis $=($ expt. - spont. $) /(100 \%$ lysis - spont. $)$. The assay was performed in triplicate wells.

Immunization and measurement of immune response in vivo. 6-10wk-old female C57BL/6 mice (Bomholtgard) were sensitized by intravenous injection of $2 \times 10^{5}$ sheep red blood cells (SRBC) (Faculty of Veterinary Medicine, Free University of Berlin, Berlin, Germany) in $100 \mu \mathrm{l}$ PBS. To assess the delayed type hypersensitivity (DTH) reaction, mice were challenged $4 \mathrm{~d}$ after immunization by injection of $2 \times$ $10^{8}$ SRBC in $50 \mu$ of PBS intracutaneously into the left hind footpad (specific swelling). Nonimmunized mice were challenged with the same dose of SRBC to determine unspecific swelling. Swelling of the footpad was measured 24 and $48 \mathrm{~h}$ after challenge with a dial gauge caliper (Oditest OD 100 T 50; H.C. Kroeplin, Schüchtern, Germany). Results were calculated by subtracting the nonspecific swelling from the specific increment. 6 or $5 \mathrm{~d}$ after primary immunization, serum was collected, and hemagglutinin titers to SRBC were measured as described (13). In brief, the serum was incubated at $56^{\circ} \mathrm{C}$ for $30 \mathrm{~min}$ and diluted using $\mathrm{NaCl} 150 \mathrm{mM}$ with or without $0.78 \%$ mercaptoethanol in serial $\log 2$ dilutions. $200 \mu \mathrm{l}$ of a $0.5 \%$ SRBC solution was added to $200 \mu \mathrm{l}$ of the serum dilutions, incubated at $37^{\circ} \mathrm{C}$ for $30 \mathrm{~min}$, at room temperature for $2 \mathrm{~h}$, and at $4^{\circ} \mathrm{C}$ for an additional $12 \mathrm{~h}$. The serum hemagglutinin titers are the highest $\log 2$ dilution steps on which hemagglutination could still be determined.

Flow-cytometric analysis and immunohistochemistry. 5 and $6 \mathrm{~d}$ after primary immunization, the mice were killed, and the left hind feet and spleens were removed. The spleens were weighed. One half of each spleen was used for APAAP staining, while the other half was used to obtain a single cell suspension by mincing each spleen through a 60 -gauge stainless steel mesh. To calculate the number of $\mathrm{CD} 3+, \mathrm{CD} 22+$, or NK1.1+ cells from each spleen, the spleen cells were counted, and aliquots of $10^{6}$ cells were stained with either PE anti-mouse CD3 (145-2C11), PE anti-mouse CD22 (Lyb-8.2), PE anti-mouse NK 1.1 (PK136), or PE-IgG (Dianova, Hamburg, Germany). Flow-cytometric analysis was performed on a FACScan ${ }^{\circledR}$ (Becton Dickinson), and the percentage of stained cells was measured in spleen cell subsets. In addition, $6-\mu \mathrm{m}$ frozen sections cut from spleens or left hind feet were fixed in acetone $(30 \mathrm{~min})$ and chloroform (30 $\mathrm{min}$ ) and stained with rat anti-mouse CD4 mAb RM4-5 (IgG2a; Dianova), rat anti-mouse CD8 mAb 53-6.7 (IgG2a; Dianova), or control mAb 23-7(IgG2a), followed by incubation with rabbit anti-rat immunoglobulins (DAKO) and APAAP rat (DAKO). Stages 2 and 3 were repeated. Incubations were performed for $30 \mathrm{~min}$, washing the sections three times in TBS between different incubation steps. Alkaline phosphatase activity was visualized by new fuchsin as described (14).

Treatment protocols. Treatment consisted of an intraperitoneal injection every $12 \mathrm{~h}$ of IL2-IgG2b at $8 \mu \mathrm{g} / 200 \mu \mathrm{l} \mathrm{PBS}$, recombinant IL-2 at $5 \mu \mathrm{g} / 200 \mu \mathrm{l}$ PBS, or control mouse anti-human mAb AHT$107 \mathrm{IgG} 2 \mathrm{~b}$ at $8 \mu \mathrm{g} / 200 \mu \mathrm{l}$ PBS. The treatment was started in two groups just before immunization and continued until $24 \mathrm{~h}$ (day 0 to day 4 ) or $48 \mathrm{~h}$ (day 0 to day 5) after challenge. In two additional groups, the treatment began simultaneously with the challenge or $24 \mathrm{~h}$ thereafter and was continued until $48 \mathrm{~h}$ after challenge.

Statistics. Statistical evaluation was performed by an analysis of variance (ONEWAY). The Bonferroni adjustment was made to the error rate of multiple comparisons. The SPSS program for MS Windows was used.

\section{Results}

Preparation of soluble IL2-immunoglobulin fusion protein. The soluble IL2-IgG2b used in this study was created by ge- 
netic fusion of cDNA encoding for mouse IL-2 to genomic DNA encoding for the Fc part of mouse IgG2b. Using the Baculo-virus expression system, we obtained fusion proteins at a concentration of $5-10 \mu \mathrm{g} / \mathrm{ml}$ supernatant, as measured by an ELISA against the mouse Fc part. The SDS-PAGE analysis revealed that the fusion proteins formed disulfide-linked dimers similar to native immunoglobulins, since the molecular weight doubled when comparing reducing with nonreducing conditions (data not shown). Whereas the calculated mass of the protein dimer was $86 \mathrm{kD}$, the measured molecular mass was $8 \mathrm{kD}$ higher, due to the glycosylation.

Characterization of in vitro function of IL2-IgG2b. The IL2$\mathrm{IgG} 2 \mathrm{~b}$ fusion protein consists of two functional domains, the IL-2 and the immunoglobulin portion. We separately tested the functionality of the IL-2 and the Fc part in vitro.

Binding of the IL2-IgG2b fusion protein to IL-2 receptors was tested by $\mathrm{FACS}^{\circledR}$ analysis, using the mouse $\mathrm{T}$ cell line CTLL-16 (Fig. 1). IL2-IgG2b, but not the control fusion protein CD16-IgG2b, stained CTLL-16 cells. The binding of IL2$\mathrm{IgG} 2 \mathrm{~b}$ to the IL-2 receptor was completely inhibited by an excess of recombinant IL-2 (Fig. 1). Further evidence for the functionality of the IL-2 moiety was obtained by analyzing the ability of the IL2-IgG2b fusion protein to support proliferation of IL-2-dependent CTLL-16 cells. Incubation of CTLL-16 cells with increasing concentrations of IL2-IgG2b resulted in a dose-dependent proliferative response comparable with that obtained with recombinant murine IL-2. Proliferation (mean \pm SD) induced by one unit of recombinant IL-2 which is equivalent to $5.8 \times 10^{-15} \mathrm{M}$ or $250 \mathrm{pg}$ IL2-IgG2b which is equivalent to $3.0 \times 10^{-15} \mathrm{M}$, as measured by scintillation counting after $\left[{ }^{3} \mathrm{H}\right]$ thymidine incorporation, was $13,960 \pm 1,240$ or $12,252 \pm$ $960 \mathrm{cpm}$, respectively, whereas the control fusion protein CD16-IgG2b did not support proliferation above the background of $1,058 \pm 120 \mathrm{cpm}$, even at a higher concentration of up to $1 \mu \mathrm{g} / \mathrm{ml}$.

Binding of the immunoglobulin portion of IL2-IgG2b to Fc receptor-bearing cells was documented using the macrophagelike cell line WEHI-3, which expresses high-affinity Fc receptors but is CD25 negative. FACS ${ }^{\circledR}$ analysis revealed that IL2IgG2b readily binds to Fc receptors on WEHI-3 cells which was blocked by mouse serum (Fig. 1). The function of IL2$\mathrm{IgG} 2 \mathrm{~b}$ bound to the cell surface via Fc receptor was also tested. Coincubation of CTLL-16 cells with an increasing number of mitomycin C-inactivated WEHI-3 cells coated with IL2-IgG2b resulted in an increasing proliferative response as measured by thymidine incorporation $(12,212 \pm 237$ to $78,518 \pm$ $435 \mathrm{cpm})$. CD16-IgG2b bound to the cell surface of WEHI-3 cells did not support proliferation of CTLL-16 cells $(308 \pm 43$ cpm) (data not shown). We further analyzed the ability of the fusion protein to mediate complement-dependent lysis of CTLL-16 cells. IL2-IgG2b lysed CTLL-16 cells more efficiently $(37 \%)$ in the presence of rabbit complement when compared with the anti-CD25 mAb (AMT13) (7.6\%) or with the control fusion protein $\mathrm{CD} 16-\operatorname{IgG} 2 \mathrm{~b}(0.1 \%)$. However, neither IL2-IgG2b nor the anti-CD25 mAb nor CD16-IgG2b induced cell lyses in the presence of mouse serum or mouse plasma (data not shown).

Effect of IL2-IgG2b on DTH. DTH is an in vivo T celldependent immune response, which has often been used as a model to follow the immunosuppressive activity of drugs, antibodies, and fusion proteins in vivo $(15,16)$. The initial sensitization period is accompanied by the homing of antigen-specific cells to the peripheral lymphoid tissues. Once activated, these cells are poised to mount the DTH response to the local site challenged with antigen. The degree of footpad swelling correlates with the extent of the DTH reaction $(16,17)$. The DTH reaction against SRBC was investigated as a measure of IL2IgG2b-mediated immunosuppression (Fig. 2). Administration of IL2-IgG2b from the time of immunization (day 0 ) until the time of challenge (day 4) resulted in an almost complete prevention of footpad swelling $24 \mathrm{~h}$ after challenge. Immunohistochemistry revealed only a marginal local infiltration of CD4+ or CD8+ cells into the footpad (Fig. 3). $48 \mathrm{~h}$ after challenge, these animals still showed significantly $(P<0.05)$ suppressed footpad swelling when compared with positive control mice receiving either mouse IgG2b or recombinant IL-2, but not complete prevention when compared with nonimmunized controls (Fig. 2). Immunohistochemistry revealed that local footpad infiltration of CD4+ and CD8+ cells increased $48 \mathrm{~h}$ after antigen challenge but remained significantly less marked than in immunized mice receiving murine $\operatorname{IgG}$ (Fig. 3). The DTH response could also be inhibited $24 \mathrm{~h}$ after challenge when IL2-IgG2b treatment was started as late as $2 \mathrm{~h}$ before challenge; however, this regimen was less effective at later time points. Once established, footpad swelling could not be reversed by subsequent application of IL2-IgG2b.

Effect of IL2-IgG2b on serum hemagglutinin titers to $S R B C$. Immunization of mice with SRBC resulted in a pronounced production of hemagglutinizing IgM antibodies against SRBC, as shown in Table I. Treatment of immunized mice with IL2-IgG2b until challenge suppressed this antibody response significantly $(P<0.05)$. When IL2-IgG2b treatment was started $2 \mathrm{~h}$ before challenge and continued until day 5 , only a marginal nonsignificant reduction of serum hemaggluti-
CTLL 16
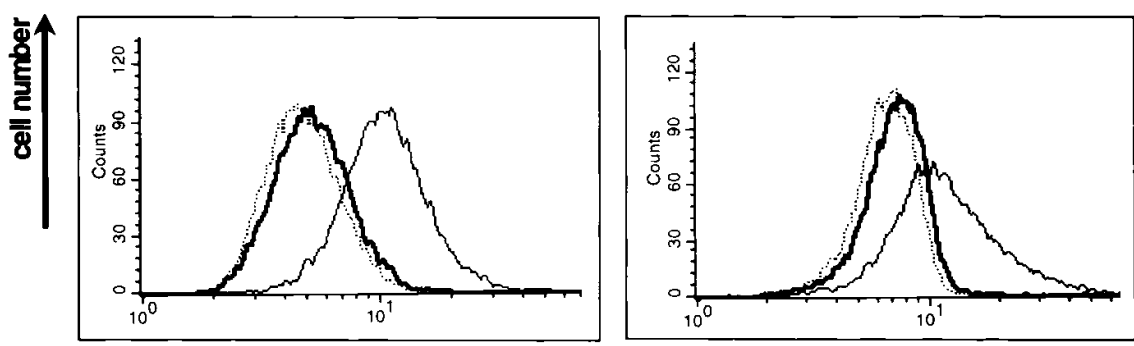

Log fluorescence intensity
Figure 1. Flow-cytometric profiles of IL2$\mathrm{IgG} 2 \mathrm{~b}$ binding to the T cell line CTLL-16 via the IL-2 receptor or to the macrophage-like cell line WEHI 3 via the $\mathrm{Fc}$ receptor (fine solid line). Binding of IL2-IgG2b to CTLL16 cells or WEHI-3 cells was inhibited by recombinant IL-2 or mouse serum, respectively (bold solid line). Staining of CTLL-16 cells with the control fusion protein CD16IgG2b and staining of WEHI-3 cells without fusion proteins are displayed as a dotted line. 


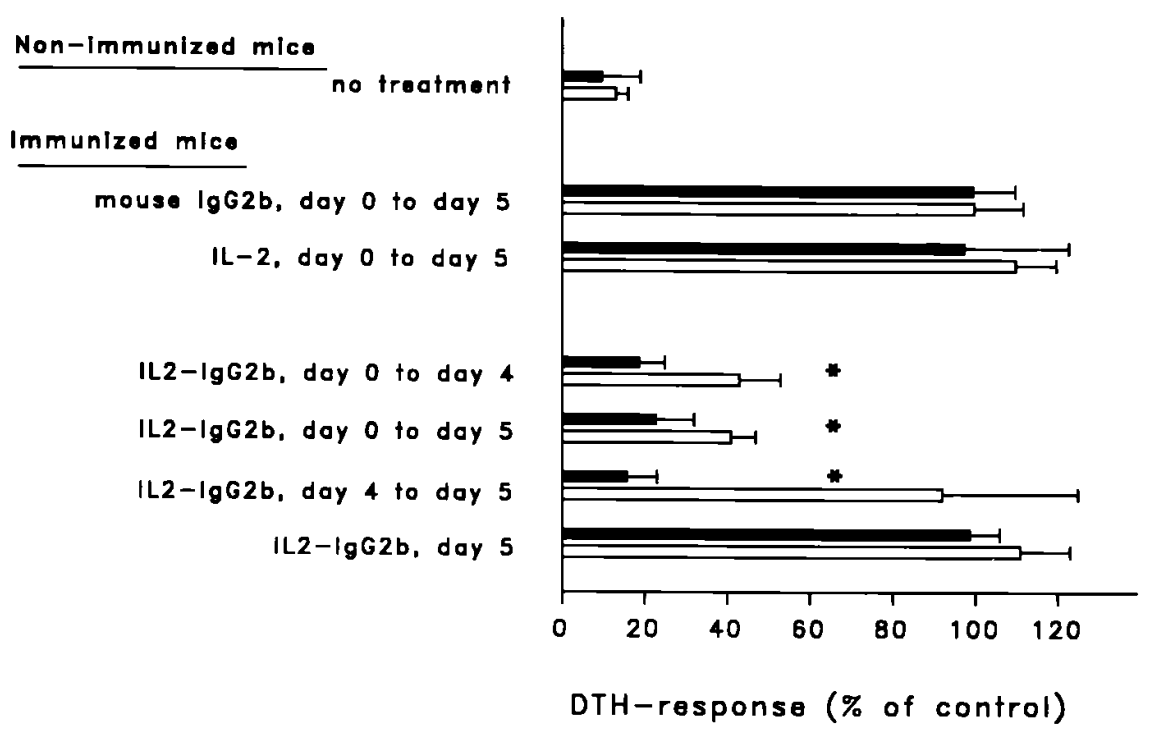

Figure 2. Effect of IL2-IgG2b on the DTH response to SRBC. Five mice in each group and experiment were immunized at day 0 and challenged at day 4. DTH response (specific footpad swelling) was measured 24 (solid bars) and $48 \mathrm{~h}$ (open bars) after challenge. Negative control mice received challenge without prior immunization. Positive control mice were treated with mouse $\mathrm{IgG} 2 \mathrm{~b}$ or recombinant IL-2. The percentage of swelling was determined by comparison with positive control mice (mean $\pm \mathrm{SD})$. Asterisks indicate statistical significance $P<0.05$; ANOVA with the Bonferroni adjustment. One representative of three independent experiments is shown. nin titers was detectable. IgG hemagglutinizing antibodies could not be detected in any of the four groups.

Effect of IL2-IgG2b on splenic lymphocytes. We further tested the composition of several lymphocyte subsets in the spleen. Treatment with IL2-IgG2b until days 4 and 5 resulted in a dramatic increase of spleen weight (Table II). When the spleen weights of immunized mice receiving mouse $\mathrm{IgG} 2 \mathrm{~b}$ and those treated with IL2-IgG2b were determined for comparison, the IL2-IgG2b-treated group showed a 52\% (from 118 to $180 \mathrm{mg}$ ) weight increase. The weight was found to be increased by $114 \%$ (from 84 to $180 \mathrm{mg}$ ) when the IL2-IgG2b-treated immunized mice were compared with nonimmunized mice. The analysis of cells contributing to this weight gain revealed a $57 \%$ increase of CD3 + cells $(P<0.05)$, a $126 \%$ increase of NK1.1+ cells $(P<0.05)$, and a $31 \%$ increase of CD22+ cells (NS) compared with immunized mice treated with $\operatorname{IgG} 2 \mathrm{~b}$ or IL2-IgG2b, respectively. Further subset analyses using APAAP staining with antibodies against CD4 or CD8 suggest that the ratio of splenic CD4+ and CD8+ T lymphocytes remained unchanged in regard to the treatment protocol (data not shown).

Table I. Effect of IL2-IgG2b on Production of Hemagglutinizing Antibodies

\begin{tabular}{lc}
\hline & $\begin{array}{c}\text { Titer of } \\
\text { hemagglutinizing } \\
\text { IgM antibodies } \\
\text { (mean log } 2 \\
\text { titer } \pm \text { SD) }\end{array}$ \\
\hline Nonimmunized mice, no treatment & $<2 \pm 0$ \\
Immunized mice, mouse IgG2b, days 0-5 & $6.6 \pm 0.54$ \\
IL2-IgG2b, days 0-4 & $<2 \pm 1.7$ \\
IL2-IgG2b, days 4-5 & $4.8 \pm 2.1$
\end{tabular}

Five mice in each group and experiment were immunized at day 0 and challenged at day 4; serum titers of hemagglutinizing IgM antibodies against SRBC were determined at day 6 . Nonimmunized mice received challenge without prior immunization. Immunized mice were treated with either mouse IgG2b or IL2-IgG2b. One representative of two independent experiments is shown.
Since the composition of splenic lymphocytes dramatically changed under treatment with IL2-IgG2b, we tested the effect of IL2-IgG2b on the proliferation of splenic lymphocytes in vitro. Similar to recombinant IL-2, the IL2-IgG2b fusion protein strongly supported the proliferation of splenic T lymphoblasts but had no effect on unstimulated spleen cells (Table III). In addition, the IL2-IgG2b fusion protein did not augment or inhibit the proliferation of resting or LPS-stimulated B cells (Fig. 4).

\section{Discussion}

Various recombinant proteins using cytokines or extracellular domains of integral membrane proteins to replace the variable regions of immunoglobulins have been developed recently to interfere with inflammatory immune responses (18-21). Based on the observation that $\mathrm{T}$ cell-dependent $\mathrm{B}$ cell differentiation requires the interaction of $\mathrm{B} 7$ with $\mathrm{CD} 28$, a chimeric protein encompassing CTLA4 fused to the constant domains of $\mathrm{IgG}$ was used to suppress $\mathrm{T}$ cell-dependent antibody responses (15). Complement-activating fusions between IL-2 and IgM were used to inhibit hypersensitivity responses (8).

In this study, we investigated the in vitro and in vivo properties of a murine IL2-IgG2b fusion protein. IL-2 was fused to $\mathrm{IgG} 2 \mathrm{~b}$, a mouse isotype with little in vivo complement fixation. IgG2b rather than IgG2a was chosen to eliminate simple complement-mediated cytolysis as a mode of immunosuppression. Binding of this chimeric protein to IL-2 receptors or cellular Fc receptors was readily demonstrated in vitro and could specifically be blocked by an excess of recombinant IL-2 or mouse serum, respectively. Soluble but also cell-bound IL2-IgG2b supported IL-2-dependent cell proliferation. Thus, both parts of the fusion protein remain functional. Moreover, the IL2IgG2b fusion protein did not support complement-mediated cell lysis. Despite the absence of immunosuppressive properties in vitro, the IL2-IgG2b fusion protein effectively inhibited DTH response in mice immunized with SRBC. This inhibition occurred despite a profound proliferation and accumulation of splenic T cells.

Both recombinant IL-2 and the IL2-IgG2b fusion protein bind high-affinity IL-2 receptors and support proliferation of T 

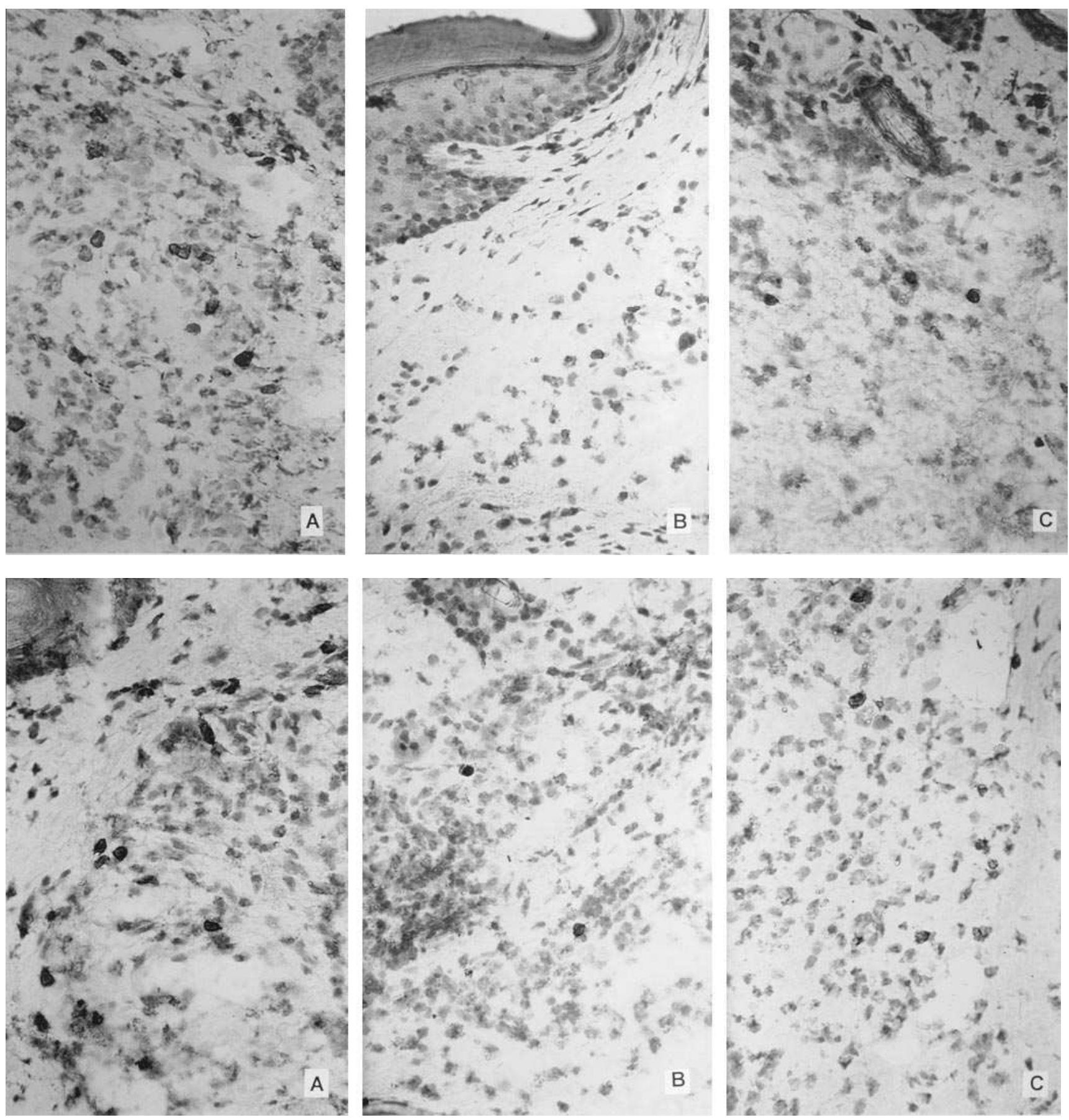

Figure 3. Analysis of CD4+ (top) and CD8+ (bottom) cells infiltrating into the footpad of immunized mice treated with either IgG2b $(A)$ or IL2$\mathrm{IgG} 2 \mathrm{~b}(B) 24 \mathrm{~h}$ after challenge. The IL2-IgG2b treatment group was also analyzed $48 \mathrm{~h}(C)$ after challenge.

cells in vitro. However, in contrast to IL2-IgG2b, recombinant IL-2 augments the DTH response to SRBC in the same mouse model (22). While IL-2 can trigger T cells to undergo apoptosis after $\mathrm{T}$ cell receptor stimulation (23), expansion of splenic $\mathrm{T}$ cells consistent with a vigorous proliferative response can be observed after application of IL-2 (22) and IL2-IgG2b; this finding strongly argues against $\mathrm{T}$ cell apoptosis as the underlying mechanism by which IL2-IgG2b suppresses DTH. The absence of complement-mediated cell lysis in the presence of murine serum favors a mechanism other than IgG-dependent cellular cytotoxicity. Although IL-2 fused to the Fc part of hu- man IgG1 or to a truncated $\operatorname{IgM}$ heavy chain mediates specific lysis of IL-2 receptor-positive cells in the presence of rabbit complement in vitro (16), the relevance of this finding for the in vivo properties of these fusion proteins remains unclear. We have no evidence that application of IL2-IgG2b results in an elimination of IL-2 binding cells in mice. The spleen of IL2IgG2b-treated immunized mice showed a marked increase in the number of CD3+ cells, CD22+ cells, and NK1.1+ cells compared with the positive control spleens from immunized mice treated with IgG2b. Moreover, the increased local accumulation of $\mathrm{T}$ cells in areas of inflammation in IL2-IgG2b- 


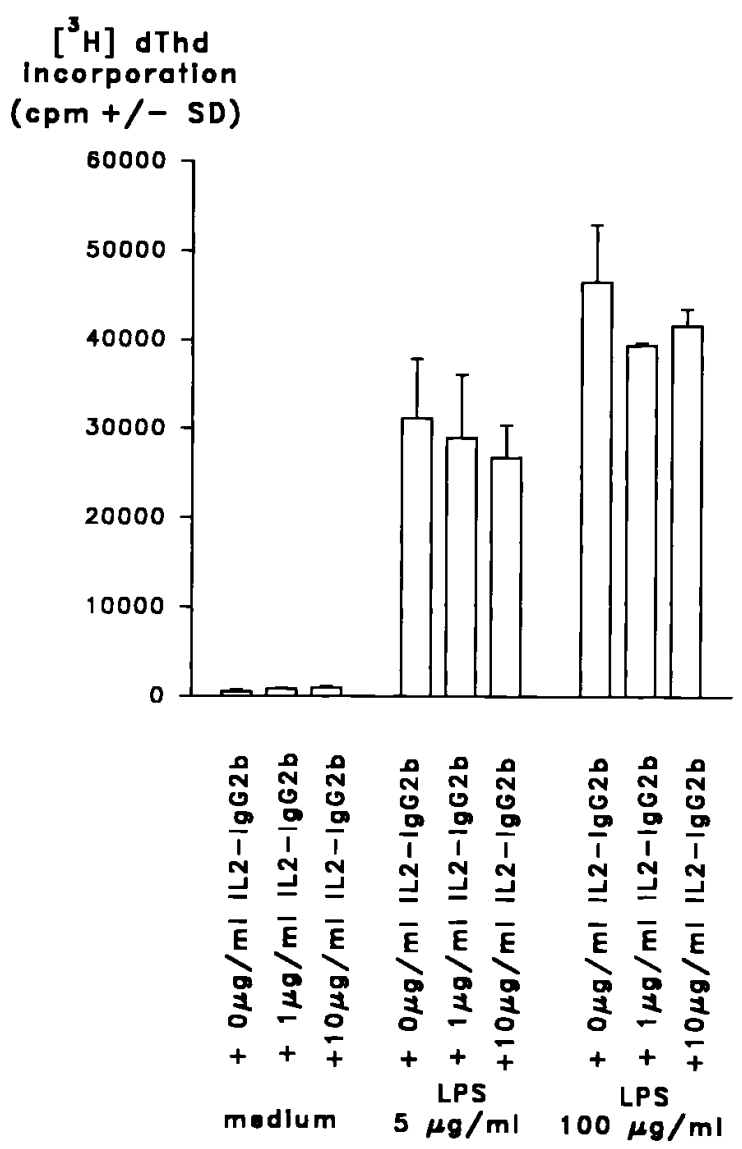

Figure 4. Influence of IL2-IgG2b on B cell proliferation induced by increasing concentrations of LPS was measured by $\left[{ }^{3} \mathrm{H}\right]$ thymidine incorporation. Data represent mean $\pm \mathrm{SD}$ of triplicate determinations and are representative of two independent experiments.

treated immunized mice from 24 to $48 \mathrm{~h}$ after challenge strongly argues against cytolysis. Similar findings have been reported after application of the CTLA4-IgG fusion protein. This fusion protein very effectively suppresses cell-mediated and humoral immune responses in mice $(5,7,15)$ but causes no deletion or alteration in subsets of T cells (24). Also, it is tempting to speculate that the CTLA4-IgG exerts its immunosuppressive action by interfering with the CD28-B7 signaling
Table III. Influence of Recombinant IL-2 or IL2-IgG2b on Proliferation of Spleen Cells or T Lymphoblasts Measured by $\left[{ }^{3} \mathrm{H}\right]$ Thymidine Incorporation

\begin{tabular}{ccc}
\hline & \multicolumn{2}{c}{$\begin{array}{c}{\left[{ }^{3} \mathrm{H}\right] \text { Thymidine incorporation }} \\
\left(\mathrm{cpm} \times 10^{3} \pm \mathrm{SD}\right)\end{array}$} \\
\cline { 2 - 3 } & Spleen cells & T lymphoblasts \\
\hline $\mathrm{IL}-2$ & & \\
$24 \mathrm{ng} / \mathrm{ml}$ & $798 \pm 65$ & $32167 \pm 367$ \\
$12 \mathrm{ng} / \mathrm{ml}$ & $346 \pm 35$ & $14594 \pm 269$ \\
$6 \mathrm{ng} / \mathrm{ml}$ & $96 \pm 23$ & $4552 \pm 199$ \\
$3 \mathrm{ng} / \mathrm{ml}$ & $368 \pm 28$ & $2820 \pm 89$ \\
$1.5 \mathrm{ng} / \mathrm{ml}$ & $696 \pm 34$ & $1907 \pm 149$ \\
$0 \mathrm{ng} / \mathrm{ml}$ & $602 \pm 54$ & $682 \pm 30$ \\
$\mathrm{IL} 2-\mathrm{IgG} \mathrm{b}$ & & $21461 \pm 351$ \\
$96 \mathrm{ng} / \mathrm{ml}$ & $199 \pm 23$ & $11962 \pm 987$ \\
$48 \mathrm{ng} / \mathrm{ml}$ & $131 \pm 121$ & $6386 \pm 110$ \\
$24 \mathrm{ng} / \mathrm{ml}$ & $157 \pm 68$ & $3495 \pm 781$ \\
$12 \mathrm{ng} / \mathrm{ml}$ & $122 \pm 23$ & $1892 \pm 367$ \\
$6 \mathrm{ng} / \mathrm{ml}$ & $313 \pm 78$ & $1002 \pm 109$ \\
$0 \mathrm{ng} / \mathrm{ml}$ & $377 \pm 33$ &
\end{tabular}

Data represent mean \pm SD of triplicate determinations and are representative of two independent experiments.

pathway; in vivo evidence to support this mode of action is sparse, and targeting of B cells to the reticuloendothelial system may alter $\mathrm{B}$ and $\mathrm{T}$ cell responses. This mechanism has also been discussed for nondepleting anti-CD25 mAb. Since IL-2 displays high receptor affinity compared with blocking antiCD25 antibodies, enormous amounts of antibodies would be required to inhibit IL-2-dependent cell proliferation in vivo, but in vivo effects have been achieved using amounts of antiCD25 mAb that would not inhibit proliferation in vitro (3). Moreover, a rat anti-mouse CD25 mAb (PC61) inhibited DTH by $40 \%$ without inhibiting IL-2-dependent cell proliferation or induction of complement-dependent cell lysis (25). It appears that the immunosuppressive mechanism of nondepleting antibodies and potentially chimeric proteins, such as the IL2-IgG2b fusion, may depend on opsonization of target cells (26). These, in turn, are retained in the reticuloendothelial system of the spleen and liver (26) and, despite vigorous proliferation, are unable to take part in the cellular immune response.

Table II. Effect of IL2-IgG2b on the Number of Spleen CD3+ T Cells, CD22+ B Cells, or NK1.1 + NK Cells and the Spleen Weight

\begin{tabular}{|c|c|c|c|c|}
\hline & $\begin{array}{l}\mathrm{CD}^{+} \text {cells } \times 10^{6} / \text { spleen } \\
(\text { mean } \pm \mathrm{SD})\end{array}$ & $\begin{array}{c}\text { NK1. } 1^{+} \text {cells } \times 10^{6} / \text { spleen } \\
(\text { mean } \pm \mathrm{SD})\end{array}$ & $\begin{array}{l}\mathrm{CD} 22^{+} \text {cells } \times 10^{6} / \text { spleen } \\
(\text { mean } \pm \mathrm{SD})\end{array}$ & Spleen $(\mathrm{mg})($ mean $\pm \mathrm{SD})$ \\
\hline Nonimmunized mice & $35.1 \pm 4.1$ & $3.6 \pm 1.0$ & $68.6 \pm 10.8$ & $87 \pm 11$ \\
\hline Immunized mice, mouse IgG2b, days $0-5$ & $47.5 \pm 6.3$ & $5.3 \pm 1.0$ & $125.5 \pm 13.3$ & $118 \pm 8$ \\
\hline IL2-IgG2b, days $0-4$ & $75.0 \pm 5.4$ & $13.9 \pm 2.6$ & $165.9 \pm 22.8$ & $188 \pm 42$ \\
\hline IL2-IgG2b, days $0-5$ & $64.1 \pm 12.6$ & $12.5 \pm 3.1$ & $127.3 \pm 33.7$ & $180 \pm 22$ \\
\hline
\end{tabular}

Five mice in each group and experiment were immunized at day 0 and challenged at day 4 . Nonimmunized mice received challenge without prior immunization. Immunized mice were treated with either mouse IgG or IL2-IgG2b. The percentage of CD3+, NK1.1+, or CD22+ cells was determined by FACS ${ }^{\circledR}$ analysis to calculate the absolute cell number of these subsets from the whole spleen cell count. One representative of two independent experiments is shown. 
The suppression of IgM antibodies in response to SRBC appears to be in sharp contrast to the effects of recombinant IL-2 and IL-2-pseudomonas toxin fusion protein, which augment the production of IgM antibodies in the same animal model (22). IL-2 receptors are present or can be upregulated on various cells, including B cells (27). Coligation of the Fc receptor FcRIIB1 with other stimulating B cell surface receptors, such as the antigen receptor or CD40, has been shown to suppress antigen-mediated B cell activation and antibody production (28-30). Although we could not demonstrate an inhibitory effect of the IL2-IgG2b fusion protein on LPS-induced B cell proliferation, simultaneous binding of the IL2-IgG2b fusion protein to Fc and IL-2 receptors could account for the decreased humoral in vivo response to immunization with SRBC. Recently, it has been shown that the interaction of activated NK cells and B cells may result in a profound suppression of IgM production in vitro (31). Since the IL2-IgG2b fusion protein can bind B cells and NK cells, it may support NK cellmediated B cell inhibition by stabilizing this cell-cell interaction.

This study demonstrates that genetically engineered fusion proteins using constant domains of immunoglobulins can profoundly alter the immune response in a manner not readily predicted by their in vitro properties. The simultaneous effect of the IL2-IgG2b fusion on cell-mediated and humoral immune responses in the absence of detectable side effects may prove useful in the treatment of allograft rejections and autoimmune diseases.

\section{Acknowledgments}

We thank Brian Seed and Alejandro Aruffo for the CD16-IgG2b fusion protein expression plasmid, and Gisela Schulz and MariaVirgilia Odenwald for excellent technical assistance.

This work was supported by the Deutsche Forschungsgemeinschaft DFG Ku 760/5-1.

\section{References}

1. Debure, A., N. Chkoff, L. Chatenoud, M. Lacombe, H. Campos, L.H. Noel, G. Goldstein, J.F. Bach, and H. Kreis. 1988. One-month prophylactic use of OKT3 in cadaveric kidney transplant recipients. Transplantation (Baltimore). 45:546-553.

2. Hourmant, M., F. Babinet, D. Cantarovich, M. Latour, J. Carcagne, H. Vie, M. Bonneville, J.F. Moreau, E. Carosella, and J.D. Bignon. 1989. Polyclonal rabbit gamma globulins against a human cytotoxic CD4 T cell clone. II. Use in prevention of rejection in kidney transplantation: a pilot study. Transplantation (Baltimore). 48:260-263.

3. Diamantstein, T., and H. Osawa. 1986. The interleukin-2 receptor: its physiology and a new approach to a selective immunosuppressive therapy by anti-IL-2-receptor monoclonal antibodies. Immunol. Rev. 92:5-27.

4. Soulillou, J.P., D. Cantarovich., B. Le Mauff, M. Giral, N. Robillard, M. Hourmant, M. Hirn, and Y. Jacques. 1990. Randomized controlled trial of a monoclonal antibody against the interleukin 2- receptor (33B3.1) as compared with rabbit antithymocyte globulin for prophylaxis against rejection of renal allografts. N. Engl. J. Med. 322:1175-1182.

5. Lenschow, D.J., Y. Zeng, J.R. Thistlethweite, A. Montag, W. Brady, M.G. Gibson, P.S. Linsle, and J.A. Bluestone. 1992. Long-term survival of xenogeneic pancreatic islet grafts induced by CTLA4Ig. Science (Wash. DC). 257: 789-792.

6. Turka, L.A., P.S. Linsley, and H. Lin. 1992. T-cell activation by the CD28 ligand B7 is required for cardiac allograft rejection in vivo. Proc. Natl. Acad. Sci. USA. 89:102-106.

7. Finck, B.K., P.S. Linsley, and D. Wofsy. 1994. Treatment of murine lupus with CTLA4Ig. Science (Wash. DC). 265:1225-1227.

8. Bogers, W.M.J.M., F. Lang, K.E. Parker, B. LeMauff, I. Anegon, Y. Jacques, and J.P. Soulillou. 1994. Rat interleukin-2 immunoglobulin M fusion proteins are cytotoxic in vitro for cells expressing the IL-2 receptor and can abolish cell-mediated immunity in vivo. Transplantation (Baltimore). 58:932939.

9. Hock, H., M. Dorsch, U. Kunzendorf, Z. Qin, T. Diamantstein, and T. Blankenstein. 1993. Mechanisms of rejection induced by tumor cell targeted gene transfer of interleukin 2, interleukin 4, interleukin 7, tumor necrosis factor, or interferon. Proc. Natl. Acad. Sci. USA. 90:2774-2778.

10. Seed, B., and A. Aruffo. 1987. Molecular cloning of the CD2 antigen, the T-cell erythrocyte receptor, by a rapid immunoselection procedure. Proc. Natl. Acad. Sci. USA. 84:3365-3369.

11. Aruffo, A., and B. Seed. 1987. Molecular cloning of two CD7 (T-cell leukemia antigen) cDNAs by a COS cell expression system. EMBO (Eur. Mol. Biol. Organ.) J. 6:3313-3316.

12. Osawa, H., and T. Diamantstein. 1984. A rat monoclonal antibody that binds specifically to mouse T lymphoblasts and inhibits IL 2 receptor functions: a putative anti-IL 2 receptor antibody. J. Immunol. 132:2445-2450.

13. Diamantstein, T., W. Keppler, E. Blitstein-Willinger, and S. BenEfraim. 1976. Suppression of the primary immune response in vivo to sheep red blood cells by B-cell mitogens. Immunology. 30:401-404.

14. Cordell, J.L., B. Falini, W.N. Erber, A.K. Gosh, Z. Abdulaziz, S. MacDonald, K.A.F. Pulford, H. Stein, and D.Y. Mason. 1984. Immunoenzymatic labeling of monoclonal antibodies using immune complexes of alkaline phosphatases and monoclonal anti-alkaline phosphatase (APAAP complexes). $J$. Histochem. Cytochem. 32:219-229.

15. Linsley, P.S., P.M. Wallace, J. Johnson, M.G. Gibson, J.A. Greene, J.F. Ledbetter, C. Singh, and M.A. Tepper. 1992. Immunosuppression in vivo by a soluble form of the CTLA-4 T cell activation molecule. Science (Wash. DC). 257:792-795.

16. Dorf, M.E., M. Collis, M.J. Whitters, R.M. O'Hara, K. Kelleher, S. Jayaraman, and V.K. Kuchroo. 1989. Antigen specific suppressor cells, receptors, and factors. Prog. Immunol. 7:874-881.

17. Luo, Y., and M.E. Dorf. 1993. Delayed-type hypersensitivity. In Current Protocols in Immunology. J.E. Coligan, A.M. Kruisbeek, D.H. Margulies, E.M. Shevach, and W. Strober, editors. John Wiley \& Sons, New York. 4.5.1-4.5.5.

18. Landolfi, N.F. 1991. A chimeric IL-2/Ig molecule possesses the functional activity of both proteins. J. Immunol. 146:915-919.

19. Vie, H., T. Gouthier, R. Breathnach, M. Bonneville, A. Godard, J. Dietrich, G. Karam, M.C. Gesnell, M.A. Peyrat, Y. Jacques, and J.P. Soulillou. 1992. Human fusion proteins between interleukin 2 and IgM heavy chain are cytotoxic for cells expressing the interleukin 2 receptor. Proc. Natl. Acad. Sci. USA. 89:11337-11341.

20. Byrn, R.A., J. Mordenti, C. Lucas, D. Smith, S.A. Marsters, J.S. Johnson, P. Cossum, S.M. Chamow, F.M. Wurm, T. Gregory, et al. 1990. Biological properties of a CD4 immunoadhesin. Nature (Lond.). 344:667-670.

21. Lenschow, D.J., Y. Zeng, J.R. Thistlethwaite, A. Montag, W. Brady, M.G. Gibson, P.S. Linsley, and J.A. Bluestone. 1992. Long-term survival of xenogeneic pancreatic islet grafts induced by CTLA4Ig. Science (Wash. DC). 257: 789-792.

22. Volk, H.D., S. Müller, S. Yarkoni, T. Diamantstein, and H. Lorberboum-Galski. 1994. Mechanisms of dichotomous action of IL-2-pseudomonas exotoxin 40 (IL-2-PE40) on cell-mediated and humoral immune response. $J$. Immunol. 153:2497-2505.

23. Lenardo, M.J. 1991. Interleukin-2 programs mouse alpha beta T lymphocytes for apoptosis. Nature (Lond.). 353:858-861.

24. Baliga, P., K.D. Chavin, L. Qin, J. Woodward, J. Lin, P.S. Linsley, and J.S. Bromberg. 1994. CTLA4Ig prolongs allograft survival while suppressing cell-mediated immunity. Transplantation (Baltimore). 58:1082-1090.

25. Dantal, J., Y. Jacquess, and J.P. Soulillou. 1991. Cluster-function relationship of rat-antimouse p55 IL-2 receptor monoclonal antibodies. Transplantation (Baltimore). 52:110-115.

26. Jonker, H., G. Goldstein, and H. Balner. 1986. Effects of in vivo administration of monoclonal antibodies specific for human $\mathrm{T}$ cell subpopulations on the immune system in a rhesus monkey model. Transplantation (Baltimore). 35: $52-58$.

27. Ortega, R.G., R.J. Robb, E.M. Shevach, and T.R. Malek. 1984. The murine IL-2 receptor. I. Monoclonal antibodies that define distinct functional epitopes on activated T cells and react with activated B cells. J. Immunol. 133: 1970-1976.

28. Abrosion, D.D., K.L. Hippen, M.A. Stacey, I. Mellman, G. Pani, K.A Siminovitch, and J.C. Cambier. 1995. Recruitment and activation of PTP1C in negative regulation of antigen receptor signaling by FcRIIB1. Science (Wash. DC). 268:293-297.

29. Phillips, N.E., and D.C. Parker. 1983. Fc-dependent inhibition of mouse B cell activation by whole anti-murine antibodies. J. Immunol. 130:602-606.

30. Lane, P., T. Brocker, S. Hubele, E. Padovan, A. Lanzaveccia, and F. McConnell. 1993. Soluble CD40 ligand can replace the normal T cell-derived CD40 ligand signal to B cells in T cell-dependent activation. J. Exp. Med. 177: 1209-1213.

31. Che, S., and D.P. Huston. 1994. Natural killer cell suppression of IgM production. Nat. Immun. 13:258-269. 